\title{
Rootstocks for Florida Stone Fruit ${ }^{1}$
}

\section{Ali Sarkhosh, Mercy Olmstead, Jose Chaparro, and Thomas Beckman²}

Rootstocks are used in many tree fruit systems to provide growth advantages and/or pest and disease resistance without affecting (or sometimes improving) productivity and fruit quality. In Florida, stone fruit are grown on rootstocks that specifically provide resistance to the peach root-knot nematode, Meloidogyne floridensis (Sherman et al. 1991; Handoo, et al. 2004). Although several root-knot nematode-resistant rootstocks are available for stone fruit grown in other locations and climates, 'Flordaguard' peach rootstock is currently the only rootstock recommended for stone fruit production in Florida.

Root-knot nematodes ( $M$. incognita and $M$. javanica) have historically been the most important species of root-knot nematodes parasitizing peach in the southeastern United States peach industry. 'Guardian', 'Nemaguard, 'Nemared', and 'Okinawa' rootstocks are resistant to these species of nematode. However, in 1966, a new species of root-knot nematode was detected on 'Nemaguard' and 'Okinawa' peach rootstocks in Gainesville, Florida, and ultimately identified as M. floridensis (Handoo et al. 2004). This nematode reproduces abundantly on 'Nemaguard' and 'Nemared' peach rootstocks, as well as on other crops (verbena, eggplant, squash, basil, impatiens, tomato, snapdragon, dill, and certain ornamental plants) (Table 1). Consequently, 'Guardian', 'Nemaguard', 'Nemared', and
'Okinawa' peach rootstocks are no longer recommended for commercial production of peaches, nectarines, and plums in Florida. Although 'Nemaguard' and 'Nemared' rootstocks had been used in north Florida for many years, the risk that $M$. floridensis might find its way into this production area suggests caution in the continued use of susceptible rootstocks.

'Flordaguard' rootstock has better resistance to $M$. floridensis than 'Nemaguard' rootstock. Field evaluation of peach rootstocks to different root-knot nematode species indicated that after 25 months, nematode egg production was greater on 'Nemaguard' than on 'Flordaguard' rootstock (Nyczepir et al. 2006). Longer-term observations in Florida also suggest that trees on 'Nemaguard' rootstock do not perform well in soils infested with $M$. floridensis. Accordingly, 'Flordaguard' rootstock is the only rootstock the University of Florida currently recommends for commercial peach production.

1. This document is HS1110, one of a series of the Horticultural Sciences Department, UF/IFAS Extension. Original publication date October 2007. Revised October 2018. Visit the EDIS website at https://edis.ifas.ufl.edu for the currently supported version of this publication.

2. Ali Sarkhosh, assistant professor and Extension specialist; Mercy Olmstead, former assistant professor and Extension specialist; Jose Chaparro, associate professor; Horticultural Sciences Department, UF/IFAS Extension, Gainesville, FL 32611; and Thomas Beckman, research horticulturalist, USDA-ARS, Southeastern Fruit and Tree Nut Research Lab, Byron, GA 31088.

The use of trade names in this publication is solely for the purpose of providing specific information. UF/IFAS does not guarantee or warranty the products named, and references to them in this publication do not signify our approval to the exclusion of other products of suitable composition. All chemicals should be used in accordance with directions on the manufacturer's label. Use pesticides safely. Read and follow directions on the manufacturer's label.

The Institute of Food and Agricultural Sciences (IFAS) is an Equal Opportunity Institution authorized to provide research, educational information and other services only to individuals and institutions that function with non-discrimination with respect to race, creed, color, religion, age, disability, sex, sexual orientation, marital status, national origin, political opinions or affiliations. For more information on obtaining other UF/IFAS Extension publications, contact your county's UF/IFAS Extension office. 


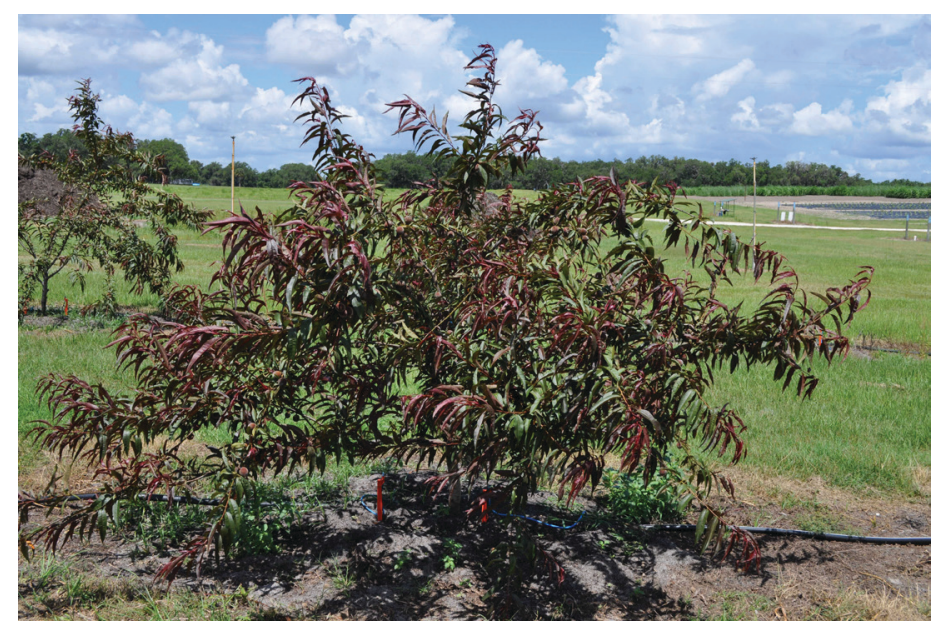

Figure 1. A 'Flordaguard' peach tree highlighted by red leaves and long, whippy branches.

Credits: M. Olmstead, UF/IFAS

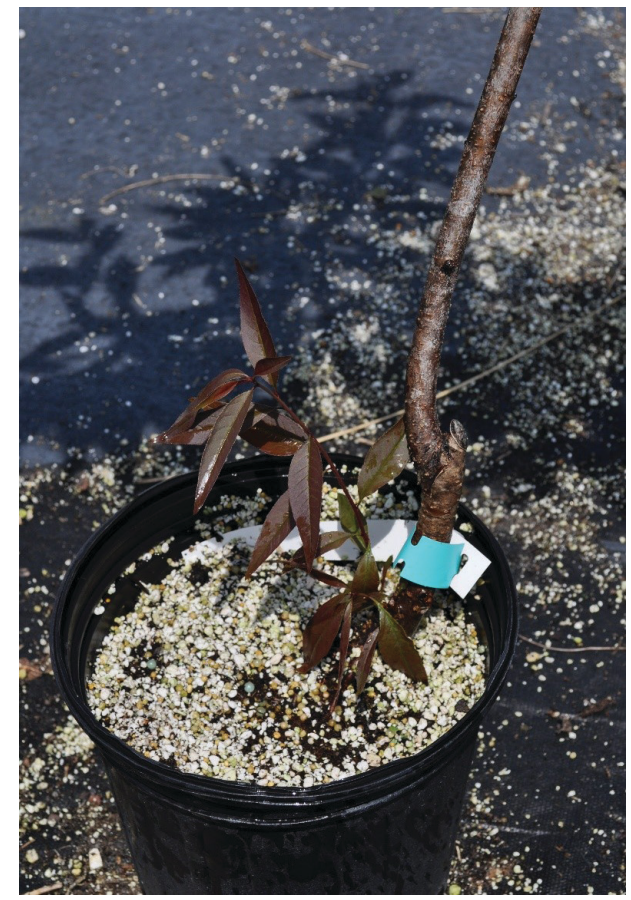

Figure 2. Budded peach tree with red-leaved 'Flordaguard' rootstock suckers.

Credits: M. Olmstead, UF/IFAS

\section{'Flordaguard' Characteristics}

The University of Florida released 'Flordaguard', a redleaved peach rootstock, in 1991 (Sherman et al., 1991). A copy of the original circular, S-376, can be found on the Florida stone fruit website at http://hortsci.ashspublications. org/content/26/4/427.full.pdf + html. It is the predominant rootstock found in orchards throughout the state especially in areas where $M$. floridensis is found.

Seedlings of 'Flordaguard' are recommended as a rootstock for low-chill peach, nectarine, and plum production in non-alkaline soils infested with peach root-knot nematodes as well as other species of root-knot nematodes.
'Flordaguard' rootstock's red-leaf trait allows for easy detection and removal of rootstock suckers (Figure 2). Rootstock suckers should be cut carefully and flush with the stem to prevent regrowth and bark injury.

\section{Production of 'Flordaguard' Seedlings for Budding with Peach Varieties}

'Flordaguard' has a chilling requirement of approximately 300 chill units and usually blooms in early February in Gainesville, FL. Trees of 'Flordaguard' grow and produce well as far south as Immokalee, Florida (100 chilling units), indicating it can also bloom and set fruit with fewer chilling units and warmer temperatures than observed in Gainesville.

'Flordaguard' trees are precocious, often fruiting the second year, and they produce many self-fertile flower buds.

Trees have long, whippy growth (Figure 1), and branches may need additional support to bear heavy crop loads. 'Flordaguard' trees can be trained to an open vase system like other peach and nectarine trees, with three to four main fruiting limbs (scaffolds). Detailed pruning can be done to remove dead or diseased limbs. Trees can set heavy crops, but fruit do not have to be thinned to produce viable seeds. Dull, red-colored fruit ripen in late June, about 130 days after bloom (Figure 6). Fruit harvesting, seed cleaning, and stratification (cold treatment) procedures are described in Table 2.

Like most peaches, 'Flordaguard' is self-fertile. Although flowers typically self-pollinate, pollen from other varieties can also fertilize 'Flordaguard'. This is known as outcrossing. Outcrossing rates in peaches are generally around 6\% (Beckman 1998). Outcrossed seedlings of 'Flordaguard' are typically susceptible to $M$. floridensis nematodes (Figure 4) and should be culled. Outcrossed seedlings can be identified because they lack dark red leaves in the new growth (Figure 3 ) and should be culled when they are approximately 6 inches tall. Another $10 \%$ of plants may need to be culled because of small stature (runts).

'Flordaguard' and its seedlings are susceptible to bark gummosis incited by the fungal pathogen Botryosphaeria dothidea, a physiological race specific to peach (Pusey 2005) (Figure 5). Scion cultivars (or the fruiting portion of the tree) budded onto 'Flordaguard' rootstock seedlings should be propagated as low as possible to reduce the amount of exposed, susceptible rootstock stem tissue. Peach trees budded onto 'Flordaguard' should be managed to reduce stress in the tree because fungal gummosis is exacerbated under 
such conditions. There is no effective chemical control for fungal gummosis.

'Flordaguard' is not recommended for use in alkaline soils. Iron deficiency symptoms commonly occur under alkaline conditions ( $\mathrm{pH}$ greater than 7.0) in calcareous soils (containing calcium and magnesium carbonates). This can result in yellowing of young leaves, called iron chlorosis.

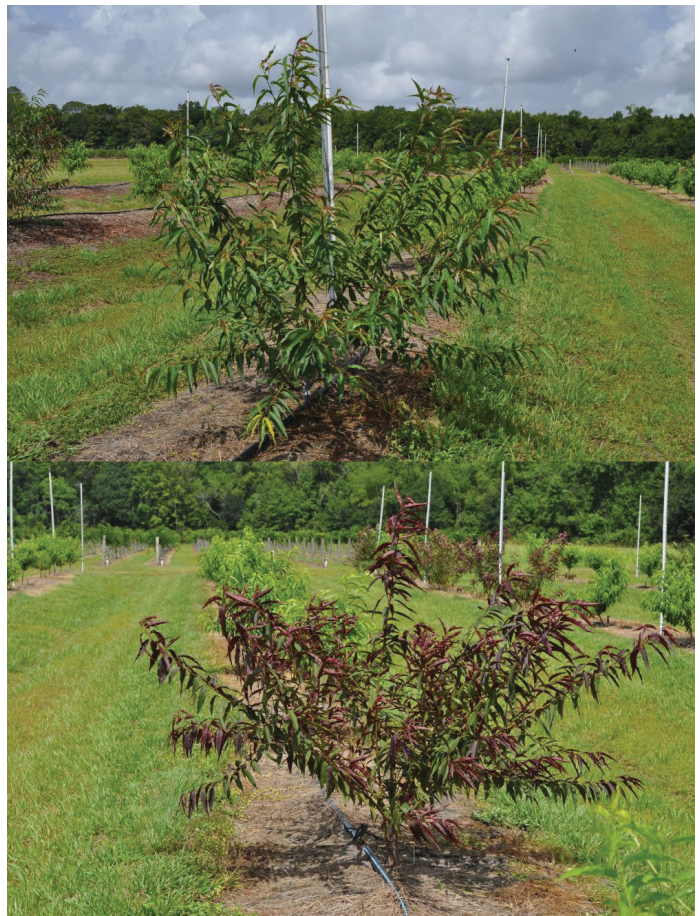

Figure 3. An outcross of 'Flordaguard' rootstock exhibiting less intensely red leaves in the new growth (top), compared with a true 'Flordaguard' rootstock exhibiting full red leaves in the new growth (bottom).

Credits: M. Olmstead, UF/IFAS

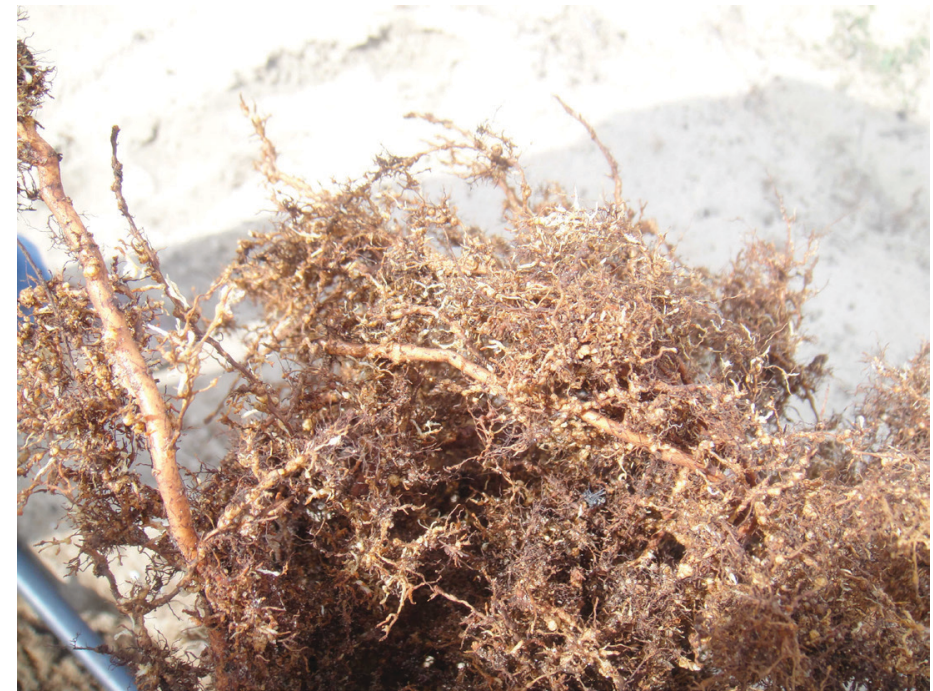

Figure 4. Nematode galls on the root system of a 'Flordaguard' outcross that was not culled during the propagation process. Credits: M. Olmstead

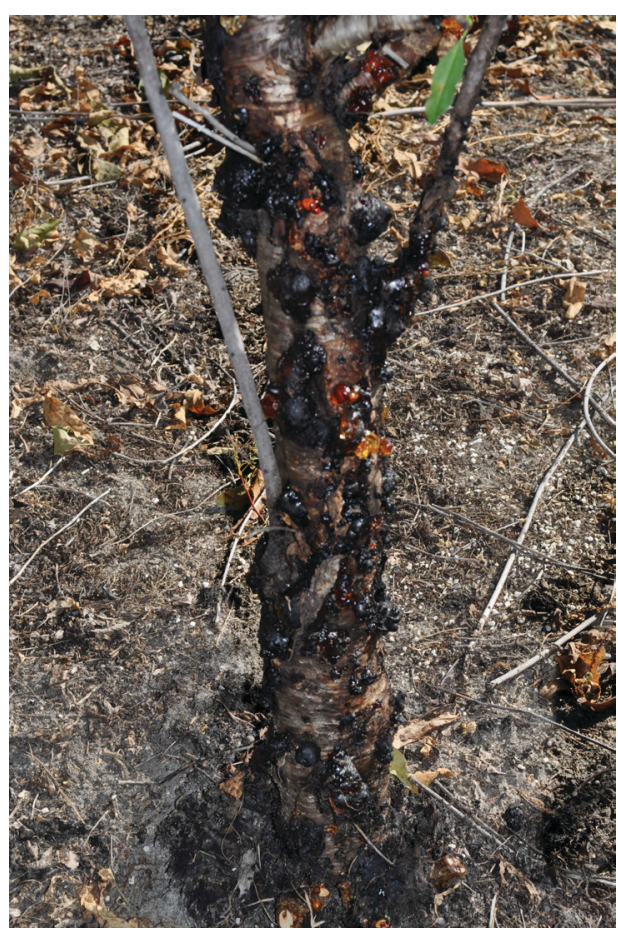

Figure 5. Gummosis on 'Flordaguard' rootstock caused by Botryosphaeria dothidia.

Credits: M. Olmstead

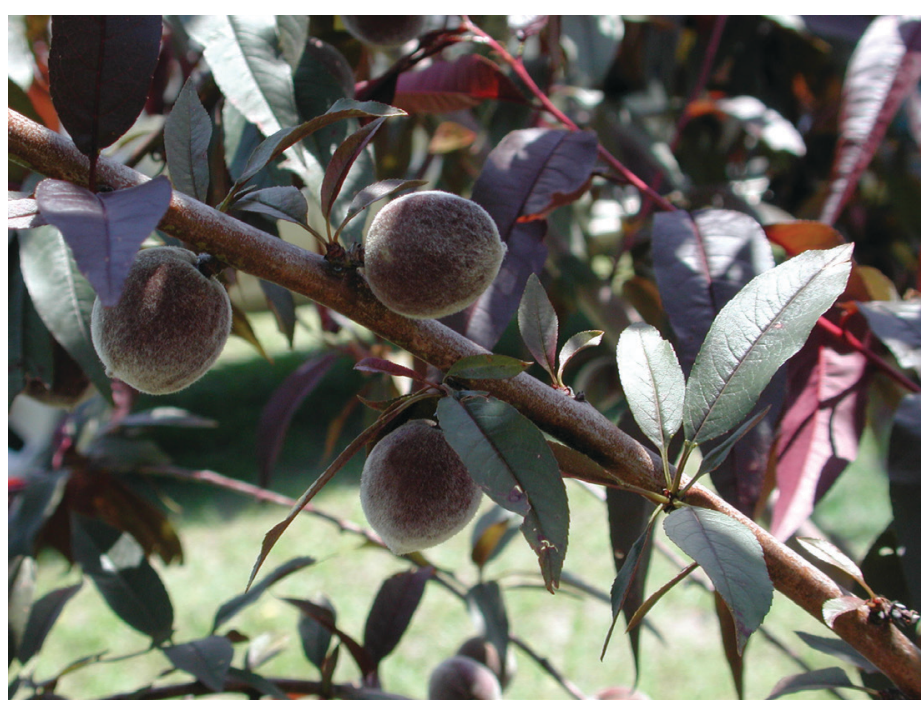

Figure 6. Red-colored fruit of 'Flordaguard' rootstock trees. Seeds from the fruit are used to produce rootstock liners for propagating orchard trees.

Credits: M. Olmstead, UF/IFAS

\section{Other Rootstocks for Florida Stone Fruit}

Two other rootstocks have recently become available for trial in both commercial and dooryards settings. 'Sharpe' rootstock, released by the USDA-ARS and the University of Florida, is a plum hybrid rootstock compatible with multiple peach and nectarine varieties (Beckman et al. 2008). Short-term tests of two standard plum varieties, 'Stanley' and 'Ozark Premier', indicate that the rootstock 
is compatible with these plum cultivars, but long term monitoring is necessary to determine the ultimate longevity of these scion/ rootstock combinations. 'Sharpe' rootstock is not compatible with apricot. 'Sharpe' rootstock is recommended (with reservations, see discussion below regarding yield and fruit size issues) for peach, nectarine, and plum varieties that are planted on sites where Armillaria root rot (Armillaria tabescens [Scop.] Dennis et al.) is present. When compared to Guardian ${ }^{\text {tw }}$ rootstock, 'Sharpe' was found to be semi-dwarfing ( $60 \%$ smaller than trees budded to Guardian $^{\mathrm{nt}}$ ) (Beckman et al. 2008). While the Armillaria resistance of 'Sharpe' and its reduced vigor offer obvious potential advantages, 'Sharpe' rootstock has an important performance issue. Trees propagated on 'Sharpe' typically have smaller fruit than from trees propagated on 'Flordaguard', even when thinned to similar crop loads. Consequently, 'Sharpe' rootstock is currently recommended only for backyard and dooryard orchards and then only with reservations regarding its potential productivity.

The newest rootstock released for grower trial is an inter-specific plum-peach hybrid, 'MP-29' (Beckman et al. 2012). 'MP-29' has red leaves similar to 'Flordaguard' which simplifies the identification and removal of rootstock suckers. 'MP-29' is resistant to Armillaria root rot and also displays good resistance to peach tree short life (PTSL), similar to that of Guardian ${ }^{\text {tw }}$ rootstock. In trials in the main production areas of middle Georgia and South Carolina, peach scions budded to 'MP-29' have displayed vigor similar to that of 'Sharpe' rootstock but with higher yields of larger fruit, which increases yield efficiency. However, at this time, field trials in north Florida are still underway and trials in central Florida have yet to be established. =Until these trials are completed, it is not possible to recommend 'MP-29' as an alternative to 'Flordaguard' rootstock.

\section{Rootstock Propagation}

'Flordaguard' rootstock can be propagated by seed or by cutting. Seeds of 'Flordaguard' trees ripen typically in late June or early July, and the fruit are small with a moderate frequency of double seeds in the pit. Fruit must be harvested before they fall off the tree because the embryo inside the pit (seed) is very sensitive to high temperatures, and prolonged exposure to heat can damage the seed. A full production schedule for 'Flordaguard' seed propagation can be found in Table 2 .

When seed supplies are short, 'Flordaguard' rootstocks can also be produced by cuttings. Softwood cuttings taken in the spring or summer are generally more successfully rooted than hardwood cuttings taken during the winter season. Softwood cuttings, approximately 8 "-10" in length, are collected from current season's growth. The basal portion (lowest 1"-2") is wounded by removing the bark from opposite sides and treated with a rooting hormone. Cuttings are then placed under greenhouse mist systems for rooting. It is important that the medium is not kept too wet because fungal disease issues can quickly kill the cuttings. The rooting pattern of cuttings may be different from that of seedlings, but preliminary research has shown that rooted cuttings of 'Flordaguard' perform as well as 'Flordaguard' seedling rootstocks in the orchard.

To ensure that cuttings are nematode-resistant, cuttings should be taken only from grafted 'Flordaguard' trees (i.e. 'Flordaguard' trees grafted or budded onto 'Flordaguard' rootstocks) rather than from 'Flordaguard' seedlings themselves. Stem cuttings taken from 'Flordaguard' seedlings may be variable in terms of nematode resistance, whereas stem cuttings taken from grafted 'Flordaguard' trees will be uniformly resistant. Seedlings can originate from the pollination of 'Flordaguard' blossoms by other cultivars, resulting in the loss of nematode resistance in those seedlings. Nurseries should, therefore, plant their grafted 'Flordaguard' trees, from which they are planning to collect seeds, in isolation from other peach trees to reduce outcrossing. If field-grown plants are to be sold or shipped, nursery site approval is required by the Division of Plant Industry to prevent spread of the burrowing nematode (Radopholus similis).

\section{References}

Beckman, T.G. 1998. Outcrossing in a diverse peach rootstock seed block. Fruit Var. J. 52:100-103

Beckman, T. G., J. X. Chaparro, and W. B. Sherman. 2008. "'Sharpe', a Clonal Plum Rootstock for Peach." HortScience. 43(7): 2236-2337.

Beckman, T. G., J. X. Chaparro, and W. B. Sherman. 2012. “'MP-29', a Clonal Interspecific Hybrid Rootstock for Peach." HortScience. 47 (1):128-131.

Handoo, Z. A., A. P. Nyczepir, D. Esmenjaud, J. G. v. d. Beek, P. Castagnone-Sereno, L. K. Carta, A. M. Skantar, and J. A. Higgins. 2004. "Morphological, Molecular, and Differential-Host Characterization of Meloidogyne floridensis n. Sp. (nematoda: Meloidogynidae), a Root-Knot Nematode Parasitizing Peach in Florida." Journal of Nematology. 36(1): $20-35$. 
Nyczepir, A. P., T. G. Beckman, and G. L. Reighard. 2006. "Field Evaluation of 'Guardian' ${ }^{\text {'T⿱ }}$ Peach Rootstock to Different Root-Knot Nematode Species." Acta Horticulturae. 713:

303-309.

Pusey, P. L. 2005. "Fungal Gummosis." In Southeastern Peach Growers Handbook. Athens: University of Georgia Press. http://www.ent.uga.edu/peach/peachhbk/fungal/ fungal.pdf.

Sherman, W. B., P. M. Lyrene, and R. H. Sharpe. 1991. "Flordaguard Peach Rootstock." HortScience. 26(4): 427-428. 
Table 1. Chilling requirement, leaf color, and nematode resistance for rootstock cultivars.

\begin{tabular}{|c|c|c|c|c|c|}
\hline Cultivar & $\begin{array}{l}\text { Chilling requirement } \\
\text { (chilling units) }\end{array}$ & Leaf color & $\begin{array}{l}\text { Meloidogyne } \\
\text { incognita }\end{array}$ & $\begin{array}{l}\text { Meloidogyne } \\
\text { javanica }\end{array}$ & $\begin{array}{c}\text { Meloidogyne } \\
\text { floridensis }\end{array}$ \\
\hline 'Flordaguard' & 300 & Red & Resistant & Resistant & Resistant \\
\hline ‘Guardian’ & $750^{z}$ & Green & Resistant & Resistant & Susceptible \\
\hline ‘MP-29' & $750^{2}$ & Red & Resistant & Resistant & Resistant \\
\hline ‘Nemaguard' & $750^{2}$ & Green & Resistant & Resistant & Susceptible \\
\hline ‘Nemared' & $650^{z}$ & Red & Resistant & Resistant & Susceptible \\
\hline ‘Okinawa' & 150 & Green & Resistant & Resistant & Susceptible \\
\hline 'Sharpe' & $500^{z}$ & Green & Resistant & Resistant & Resistant \\
\hline
\end{tabular}

Table 2. Suggested schedule for peach nursery practices.

\begin{tabular}{|c|c|}
\hline \multicolumn{2}{|r|}{ Year 1} \\
\hline June & $\begin{array}{l}\text { Propagation by seed: } \\
\text { Harvest 'Flordaguard' seeds from budded 'Flordaguard' trees. Do not collect seed from unbudded seedlings of } \\
\text { 'Flordaguard'. Remove fruit flesh and dry pits at room temperature for } 3-4 \text { days. Store pits under dry conditions } \\
\text { in a paper bag at } 45^{\circ} \mathrm{F} \text {. } \\
\text { Pits that have been dried and stored at } 45^{\circ} \mathrm{F}\left(7.2^{\circ} \mathrm{C}\right) \text { for } 2.5 \text { years have not shown a significant reduction in } \\
\text { germination percentage. } \\
\text { Propagation by cuttings: } \\
\text { Take softwood cuttings to propagate under mist. Cuttings can be collected for ca. } 2 \text { months. Transplant rooted } \\
\text { cuttings to containers, wean under mist, and grow until the following May or June. }\end{array}$ \\
\hline November & $\begin{array}{l}\text { Remove pits from storage. } \\
\text { Remove seeds from pits. } \\
\text { Soak seeds in water for } 5 \text { days. It is very important to discard water and replace with clean water every day } \\
\text { during this period. This treatment increases the seed germination percentage. } \\
\text { Stratify seeds in moist peat or perlite treated with a soluble fungicide (e.g. Captan) at } 45^{\circ} \mathrm{F}\left(7.2^{\circ} \mathrm{C}\right) \text { for } 40-60 \\
\text { days before planting. } \\
\text { When the radicle has emerged from the seed coat, seeds are ready for planting in trays. }\end{array}$ \\
\hline \multicolumn{2}{|r|}{ Year 2} \\
\hline January-February & $\begin{array}{l}\text { Seedlings that are } 8 "-12^{\prime \prime} \text { tall should be transplanted into pots in a greenhouse environment. } \\
\text { Cull seedlings that do not have dark red growing tips (i.e. probable outcrosses) or are significantly slower } \\
\text { growing (i.e. runts). }\end{array}$ \\
\hline February-June & Fertilize and irrigate seedlings. \\
\hline May-June & $\begin{array}{l}\text { Bud-graft 'Flordaguard' rootstock liners with desired scion cultivar. The bud should not contain xylem or woody } \\
\text { fibers. Phony peach disease (Xylella fastidiosa) can be transmitted by bud-grafting budwood material that } \\
\text { includes woody vascular (xylem) tissue. }\end{array}$ \\
\hline June-January & $\begin{array}{l}\text { Plant spring- or summer-budded trees in the field through the end of October. Be sure to irrigate newly } \\
\text { established trees through dormancy. } \\
\text { Bare-root trees can be planted during the winter season when trees are dormant. Irrigation helps to keep the } \\
\text { roots moist and prevent freeze damage. }\end{array}$ \\
\hline
\end{tabular}

